\title{
First record of the ant-loving cricket Myrmecophilus crenatus Gorochov, 1986 (Orthoptera, Myrmecophilidae) in Kazakhstan
}

\author{
Izbasar I. Temreshev' \\ I LLP "Ecoservice-C", 050009, Almaty, 202a Tole Bi St, Office 408, Kazakhstan \\ Corresponding author: Izbasar I. Temreshev (temreshev76@mail.ru)
}

Academic editor: R. Yakovlev | Received 10 May 2020 | Accepted 29 June 2020 | Published 6 November 2020

http://zoobank.org/328F5ADF-A4FC-487F-95F3-FA7295BB2512

Citation: Temreshev II (2020) First record of the ant-loving cricket Myrmecophilus crenatus Gorochov, 1986 (Orthoptera, Myrmecophilidae) in Kazakhstan. Acta Biologica Sibirica 6: 407-412. https://doi.org/10.3897/ abs.6.e54135

\begin{abstract}
The ant-loving cricket Myrmecophilus crenatus Gorochov, 1986 was found in the Turkestan oblast of southern Kazakhstan. This is the first species record for this area. Thus, the current fauna of ant-loving crickets in Kazakhstan includes three species - Myrmecophilus crenatus, M. acervorum (Panzer, 1799) and Bothriophylax semenovi (Miram, 1930).
\end{abstract}

\section{Keywords}

New record, Myrmecophilus crenatus, crickets, ant guest, Kazakhstan

\section{Introduction}

Ant-loving crickets (Myrmecophilidae Saussure, 1874) are the obligate inquilines within ant and termites nests or burrows of various rodent and other vertebrate species. The crickets are very small, wingless and flattened, yellow, brown or nearly black in color. Ant-loving crickets do not produce sound and lack both wings and tympanal organs on the front tibia. Two subfamilies - Botryophilacinae Miram, 1934 (vertebrates guest) and Myrmecophilinae Saussure, 1874 (ant and termites

Copyright Izbasar I. Temreshev. This is an open access article distributed under the terms of the Creative Commons Attribution License (CC BY 4.0), which permits unrestricted use, distribution, and reproduction in any medium, provided the original author and source are credited. 
guest). They containing 6 genus and fewer than 100 species. In Kazakhstan, the fauna of ant-loving crickets has not been studied enough. Up to the present time only 2 species - Bothriophylax semenovi (Miram, 1930) and Myrmecophilus acervorum (Panzer, 1799) (Childebaev \& Storozhenko 2004; Childebaev et al. 2014) were known in Kazakhstan fauna.

Ant-loving cricket Myrmecophilus crenatus Gorokhov, 1986 belongs to the subgenus Paramyrmecophilus Gorochov, 1986 of the genus Myrmecophilus Borowiec, 1984 of the subfamily Myrmecophilinae of the family Myrmecophilidae. The male body length is $2.4 \mathrm{~mm}$, female is $2.6 \mathrm{~mm}$ long; pronotum of male is 0.8 ; female is 0.9 ; hind femur is 1.5 in both sexes; ovipositor is $1.1 \mathrm{~mm}$. Coloring is light, yellowish. Head with small dark eyes. The width of the antennal cavities is approximately 1.5 times less than the distance between them. The apical segment of the maxillary palps is almost 2 times longer than the $3 \mathrm{rd}$ segment and approximately 2.5 times longer than the 4 th segment. The width of the hind femur is almost 1.5 times less than its length. Hind tibia about 1.4 times shorter than hind femur. The upper edge of the hind tibia is almost straight, and the lower one is arched. On the outside of the hind tibia there are 1 spike and 3 spurs. The longest of them is superior, equal in length to half of the hind tibia. The spike is almost 2 times shorter than it. The average spur is 1.5 times shorter than the spike. The lower spur is almost 2 times shorter than the average. A slightly darker transverse strip extends along the posterior edge of the tergites of the chest and abdomen. Cerci more or less elongated, equal in length to the hind tibia. Ovipositor slightly longer than hind tibia. The top of the internal folds of the ovipositor is wide, with almost identical large teeth. The view was described by A.V. Gorokhov from the Mogoltau mountains on Uzbekistan-Tajikistan border (Gorochov 1986, Cigliano et al. 2019). Like many other members of the family, it is an obligate inquiline of ants.

\section{Key of the species of Myrmecophilidae of Kazakhstan}

1(2) The body is not disc-shaped. The head is hypognatic. The antennae are very long. The lateral pronotum lobes not bent under the disc. The legs are quite long. Front and middle coxae short. Hind legs with slender thighs and long legs, equipped with long and rare spikes. Cerci long and thin. Ovipositor is not retractable

\section{.....Botryophilacinae Miram, 1934. The only species Bothriophylax semenovi (Miram, 1930)}

2 (1) The body is disc-shaped. The head is opistognathic. Antennae only slightly longer than body. The lateral pronotum lobes bent under the disc. The legs are relatively short. Front and middle coxae long. Hind legs with very wide hips and short legs, equipped with long and rare spikes. Cerci short, thick. Retractable ovipositor Myrmecophilinae Saussure, 1874

3 (5) On the inside of the hind tibia there are 4 spines. First and third spikes longer than second and fourth subgenus Myrmecophilus Berthold, 1827 
4 (6) Coloring is brownish-red, matte, sometimes with light bandages. Body length 2.5-3.0, ovipositor length 0.9. Cerci short, thick

Myrmecophilus acervorum (Panzer, 1799)

5 (3) On the inside of the hind tibia there are 3 spines. First is the longest spike, third spike - the shortest..... subgenus Paramyrmecophilus Gorochov, 1986

6 (4) Coloring is light, yellowish. Body length 2.4-2.6, ovipositor length 1.1. Cerci elongated, approximately equal in length to hind tibia.

Myrmecophilus crenatus Gorochov, 1986

\section{Material and methods}

The material was collected in the Turkestan region (formerly South Kazakhstan) within the project "Comprehensive assessment of the state of the environment and the health of the population of the city of Kentau and surrounding settlements" section "Assessment of the State of the Fauna of the Kentau City Agglomeration". The species was determined by I.I. Temreshev. For the identification, clarification of the biology and distribution of the cricket ant we referred to Gorochov $(1980,1986)$, Storozhenko (2004), and Cigliano et al. (2019). To determine the social insects in the nests of which $M$. crenatus was found, sources from the list of literature were used (Dlussky 1981, Seifert 2012, Zhuzhikov 1979). Material is stored in the personal collection of authors.

\section{Results}

For Kazakhstan M. crenatus is indicated by us for the first time. It was discovered in the vicinity of the village of Bayaldyr and in the vicinity of the village of Karnak in Turkestan oblast at different points quite distant from each other.

Material examined. 1 female, 19.10.2019, Turkestan oblast, Kentau city agglomeration, neighborhood Karnak village, in a nest of Turkestan termite Anacanthotermes turkestanicus Jacobson, 1904, under a stone, I.I. Temreshev; 1 male, 1 female, 22.10.2019, Turkestan region, Kentau city agglomeration, neighborhood Bayaldyr village, in the nest of the ant Tapinoma erraticum (Latreille, 1798), under a piece of concrete on a semi-desert site, I.I. Temreshev; 1 male, 03.15.2020, Turkestan region, Kentau city agglomeration, neighborhood Bayaldyr village, in the nest of the ant $T$. erraticum, under a stone on a semi-desert site, I.I. Temreshev (Figs 1-3).

\section{Discussion}

We discovered the ant-loving cricket in the nest of T. erraticum that allows us to more accurately evaluate its hosts, since the original description (Gorochov 1986) 

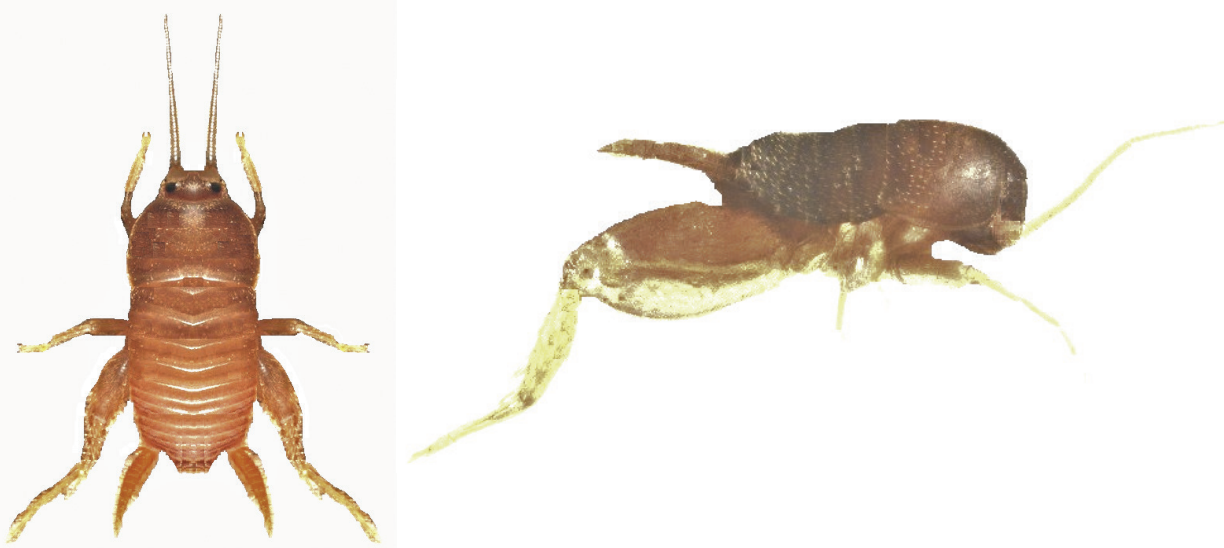

Figure I. Ant-loving cricket Myrmecophilus crenatus Gorochov, 1986 from Kazakhstan

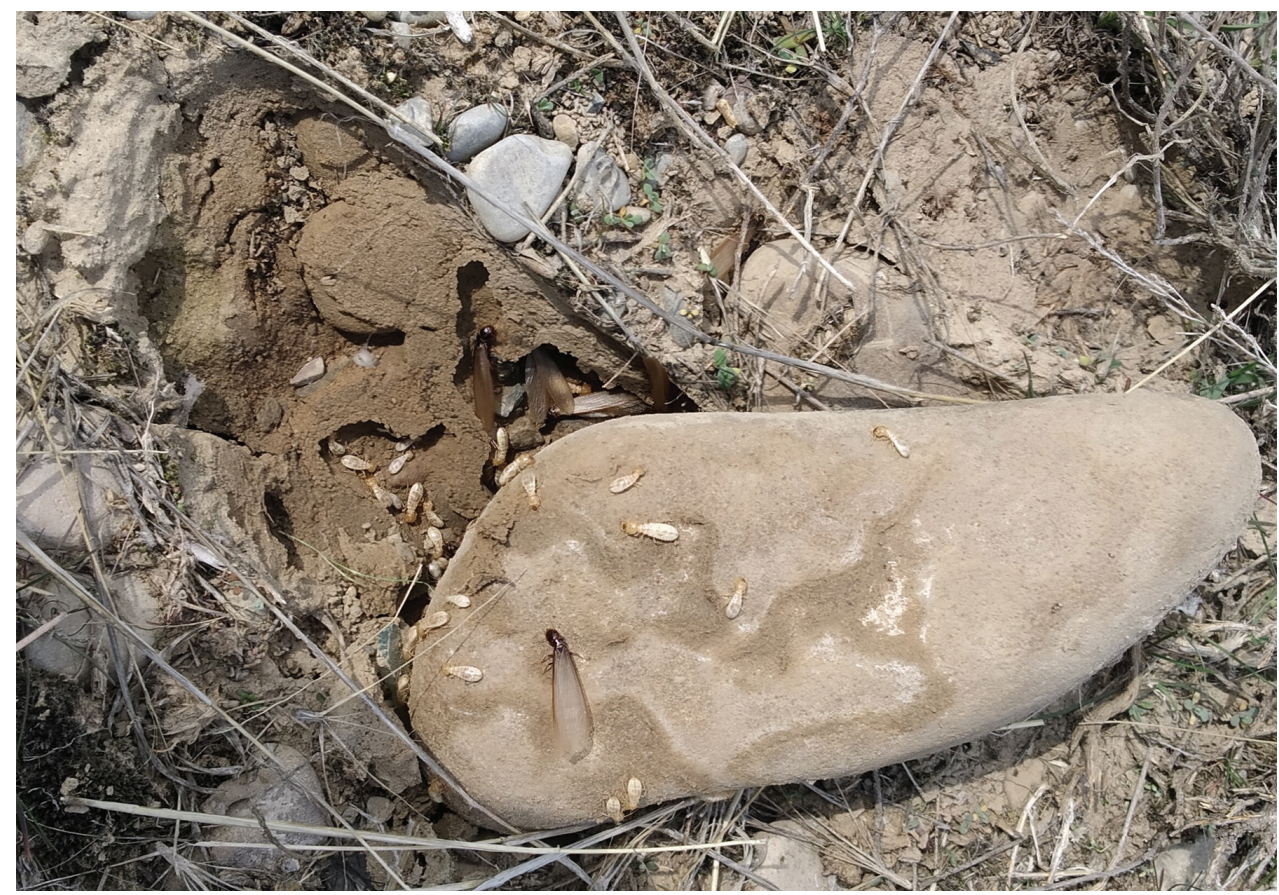

Figure 2. Nest of Turkestan termite Anacanthotermes turkestanicus Jacobson, 1904, where the ant-loving cricket Myrmecophilus crenatus Gorochov, 1986 was found

simply indicates "anthill" for the holotype. We supposed that the occurrence of antloving cricket in the nest of the Turkestan termite A. turkestanicus, was rather accidental, since there were anthills of different ant species T. erraticum, Messor aralocaspius (Ruzsky, 1902), and Cataglyphis aenescens (Nylander, 1849). It is possible 


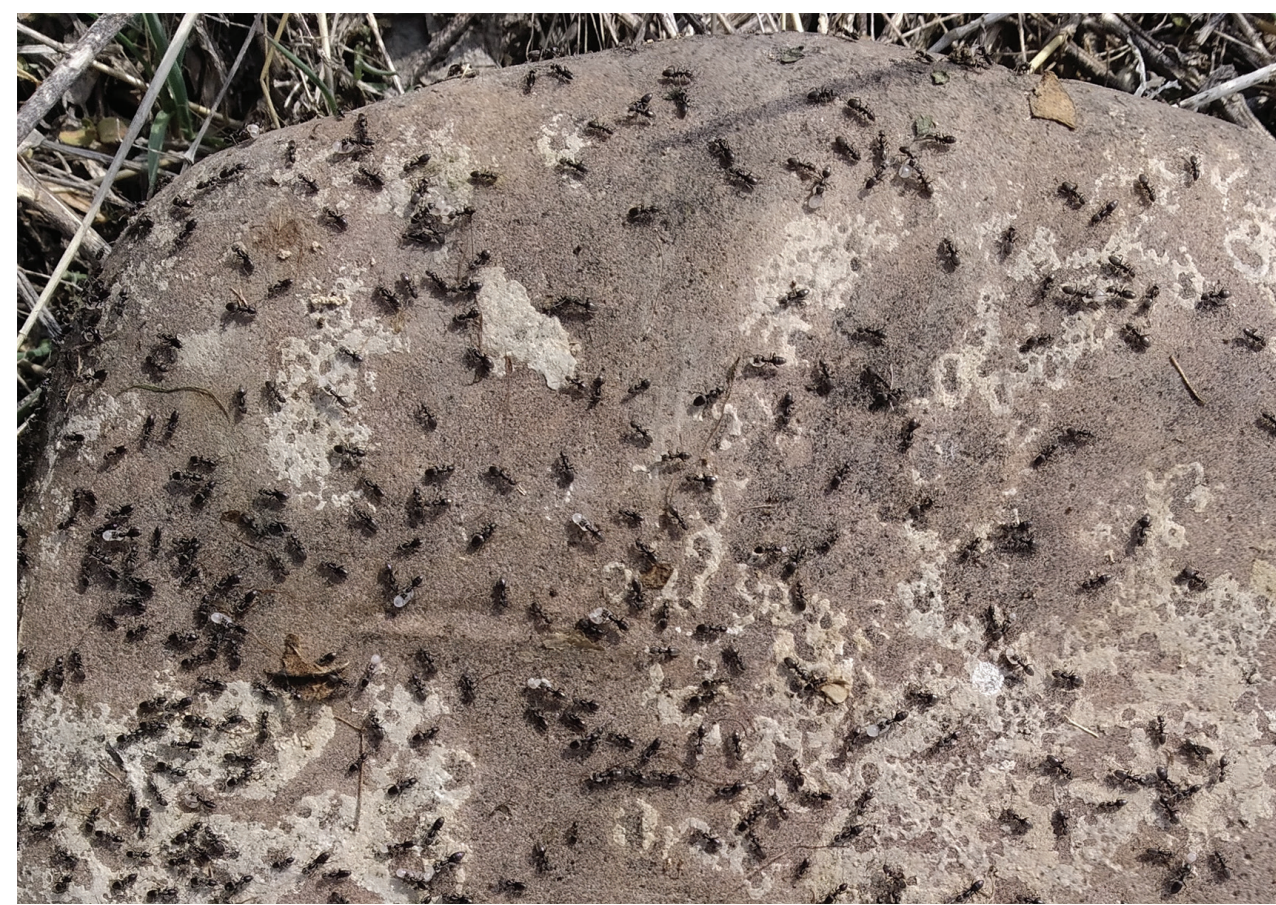

Figure 3. Nest of ant Tapinoma erraticum (Latreille, 1798), where the ant-loving cricket Myrmecophilus crenatus Gorochov, 1986 was found

that a female of ant-loving cricket was found in a nest of Turkestan termite due to resettlement (sort of "transshipment base" during migration).

The ant-loving cricket was not previously observed in Kazakhstan (Childebaev \& Storozhenko 2004). We suggested that the M. crenatus probably inhabit the Kentau city agglomeration (the Turkestan region, Kazakhstan), but was not found due to its rarity. This is its main difference from another ant cricket $M$. acervorum, which is invasive species in Kazakhstan (Childebaev et al. 2014) and neighboring Uzbekistan (Lebedeva 2017). In future, additional finds of $M$. crenatus are possible in other areas of the south Kazakhstan. Thus, now Myrmecophilidae family in the Republic of Kazakhstan includes 3 species - M. crenatus, $M$. acervorum and B. semenovi.

\section{Acknowledgements}

The work was carried within the framework of the project "Comprehensive assessment of the state of the environment and the health of the population of the city of Kentau and surrounding settlements" section "Assessment of the state of the fauna of the Kentau city agglomeration". 


\section{References}

Cigliano MM, Braun H, Eades DC, Otte D (2019) Orthoptera Species File Online. Version 5.0/5.0. Available from: http://Orthoptera.SpeciesFile.org. (Retrieval date 26.11.2019).

Childebaev MK, Storozhenko SYu (2004) An annotated list of the long-horned orthopterans (Orthoptera, Ensifera) of Kazakhstan. Tethys Entomologycal Research 9: 213-228. [In Russian]

Childebaev MK, Temreshev II, Kolov CV (2014) Myrmecophilus acervorum (Panzer, 1799) (Orthoptera, Myrmecophilidae) - first records ant-loving cricket for the fauna of Kazakhstan. Euroasian entomological journal 13 (3): 246. [In Russian]

Dlussky GM (1981) Desert Ants. Moscow: Nauka. 230 p. [In Russian]

Gorochov AV (1980) Crickets of the genera Eremogryllodes Chop. and Myrmecophilus Berth. (Orthoptera, Gryllidae) and systematic position of the tribe Bothriophylacini. Entomologycal Revue 59 (2): 287-293.

Gorochov AV (1986) New and little-known crickets (Orthoptera, Grylloidea) from Middle Asia and adjancet territory. Proceedings of the Zoologycal Institute of Academy of Sciences USSR, Leningrad 140: 3-15. [In Russian]

Lebedeva NI (2017) First record of Myrmecophilus (Myrmecophilus) acervorum Panzer, 1799 (Orthoptera, Myrmecophilidae, Myrmecophilinae) from Uzbekistan. East European Scientific Journal 3 (19): 4-8.

Seifert B (2012) Clarifying naming and identification of the outdoor species of the ant genus Tapinoma Forster, 1850 (Hymenoptera: Formicidae) in Europe north of the Mediterranean region with description of a new species. Myrmecological News 16: 139-147.

Storozhenko SYu (2004) Long-billed orthopteran insects (Orthoptera: Ensifera) of the Asian part of Russia. Vladivostok: Dal'nauka. 280 p. [In Russian]

Zhuzhikov DP (1979) Termites of the USSR. Moscow: Publishing House Moscow University. 225 p. [In Russian] 